\title{
Pemanfaatan Aplikasi Wattpad Dalam Memotivasi Siswa Untuk Menulis Cerita
}

\author{
Ria Ananda Putri \\ Universitas Muhammadiyah Sumatera Utara \\ e-mail: ria.ap@gmail.com
}

\begin{abstract}
Social media is a online media, with the users can easily participate, share, and created the blog, covering social network, wiki, forum and virtual world. Now, many one who uses social media especially teenagers. Teenager in indonesia often takes social media to channel their creativity. One of them is from writing. Inordinate social media that can be used to channel from writing. Research methodology used the research is research methodology qualitative, interpret how the role the application wattpad in motivate students for writing a story is a data collection. he result of research that is done in minutely student average by researchers, in general have motivation and desire to write wattpad applications .Although some of them have not dare do it with reason lacking in confidence. But , there are face the its position not only as the reader, will also active as a writer to keep writing motivated and be able to .
\end{abstract}

Key Word: Wattpad, Motivation, Students, and Writing.

\begin{abstract}
Abstrak
Media sosial adalah sebuah media online, dengan para penggunanya bisa dengan mudah berpartisipasi, berbagi, dan menciptakan isi meliputi blog, jejaring sosial, wiki, forum dan dunia virtual. Saat ini, sudah banyak orang yang menggunakan media sosial terutama para remaja. Anak remaja di Indonesia kerap menggunakan media sosial untuk menyalurkan kreatifitasnya. Salah satunya yaitu kreatifitas menulis. Banyak sekali media sosial yang bisa digunakan untuk menyalurkan kreatifitas menulis. Metode penelitian yang digunakan dalam penelitian ini adalah metode penelitian kualitatif, yaitu untuk menafsirkan bagaimana peranan aplikasi Wattpad dalam memotivasi siswa untuk menulis cerita dengan teknik pengumpulan data yang ada. Hasil dari penelitian yang dilakukan rata-rata siswa yang di teliti oleh peneliti, pada umumnya punya motivasi dan keinginan untuk menulis di aplikasi Wattpad. Walaupun sebagian dari mereka belum berani melakukan hal itu dengan alasan kurang percaya diri. Namun, ada siswi yang posisinya tidak hanya sebagai pembaca, tetapi juga aktif sebagai penulis dan termotivasi untuk terus menulis.
\end{abstract}

Kata kunci : Wattpad, Motivasi, Siswa, dan Menulis. 
Latar Belakang Masalah

Munculnya internet dapat menghubungkan antar manusia dari berbagai belahan dunia yang tidak saling kenal sebelumnya dengan cara mengkoneksikan komputer dengan jaringan internet. Menurut Alwi (2000) Internet merupakan aringan komputer yang sangat besar, terdiri dari jutaan perangkat komputer yang terhubung sebagai pertukaran informasi diantara pemakai komputer. Komputer merupakan salah satu media elektronik yang sangat canggih, yang mana di komputer terdapat program yang dikenal dengan nama internet. Dengan komputer program internet dapat dioperasikan, bahkan hampir semua orang di seluruh dunia menggunakan komputer sebagai sarana mengoperasikan internet.

Interaksi antar manusia tersebut bertujuan untuk memenuhi kebutuhan hidup baik kebutuhan jasmani maupun rohani. Salah satunya adalah kebutuhan informasi. Sebagian besar masyarakat dunia kini menggunakan internet, bahkan bisa dikatakan hampir semua orang khususnya di perkotaan telah mengenyam akses internet. Seiring berjalannya waktu internet berkembang dengan sangatlah pesat. Bagaimana tidak, yang tadinya hanya bisa dinikmati orang-orang tertentu saja dan fungsinya pun terbatas, kini semua orang bisa menggunakannya tanpa terkecuali dengan akses informasi yang jauh lebih luas dan fungsi yang lebih beragam. Banyak orang yang sangat tergantung pada internet dalam kehidupan sehariharinya, mulai dari pemakaian media sosial sebagai hiburan atau bisnis, membaca artikel menarik di website, hingga kegiatan chatting dengan kawan terdekat.

Perkembangan teknologi komunikasi yang sangat pesat saat ini, maka diperkirakan pabrik teknologi komunikasi memproduksi berbagai varian teknologi komunikasi setiap hari di pabrik mereka. Saat ini setiap hari, setiap minggu masyarakat dapat menyaksikan berbagai produk teknologi komunikasi baru sebagai hasil konvergensi dari berbagai teknologi komunikasi yang sebelumnya telah dikembangkan, sehingga kadang masyarakat kebingungan dan tercengang dengan temuan baru itu (Bungin; 2013). 
Media sosial sebagaimana dijelaskan Nasrullah (2015) adalah medium di internet yang memungkinkan pengguna merepresentasikan dirinya maupun berinteraksi, bekerja sama, berbagi, berkomunikasi dengan pengguna lain membentuk ikatan sosial secara virtual. Sementara itu Kaplan dan Haenlein (2010) menjelaskan media sosial merupakan sekelompok aplikasi berbasis internet yang dibangun di atas dasar ideologi dan teknologi web 2.0 dan memungkinkan penciptaan dan pertukaran User generated contet.

Sebuah media online, dengan para penggunanya bisa dengan mudah berpartisipasi, berbagi, dan menciptakan isi meliputi blog, jejaring sosial, wiki, forum dan dunia virtual. Blog, jejaring sosial dan wiki merupakan bentuk media sosial yang paling umum digunakan oleh masyarakat di seluruh dunia. Ada banyak sekali manfaat dari media sosial, diantaranya untuk bersosialisasi, penyalur hobi, mencari informasi, dan masih banyak lagi termasuk menyalurkan kreativitas. Saat ini, sudah banyak orang yang menggunakan media sosial terutama para remaja. Anak remaja di Indonesia kerap menggunakan media sosial untuk menyalurkan kreatifitasnya. Salah satunya yaitu kreatifitas menulis. Banyak sekali media sosial yang bisa digunakan untuk menyalurkan kreatifitas menulis. Di media sosial kita bisa dengan bebas mengeluarkan kemampuan kita dalam hal menulis, seperti blog, facebook, line, Wattpad, dan masih banyak lagi.

Wattpad adalah salah satu situs online yang diperuntukan bagi penggunanya yang gemar menulis, baik itu menulis artikel, cerita pendek, cerita bersambung atau pun puisi. Diluncurkan tahun 2006, Wattpad yang didirikan dari hasil kolaborasi Allan Lau dan Ivan Yuen ini berbasis di Toronto, Kanada. Dalam perkembangannya secara perlahan tapi pasti Wattpad mulai menyebar ke beberapa Negara di antaranya Amerika, Inggris, Australia, Filipina, Rusia, Libya, Jamaika, Uni Emirat Arab dan tentu saja Indonesia dan beberapa Negara lain di penjuru dunia.

Dengan membuat akun gratis untuk mulai menulis di Wattpad atau sekedar membaca postingan- 
postingan di Wattpad, baik itu cerita pendek, cerita bersambung, artikel ataupun puisi. Juga dapat memberikan sebuah komentar dan vote pada setiap bacaan. Wattpad juga mempunyai kemampuan untuk di baca di komputer, telepon, atau tablet pembacanya.

Untuk yang hobi membaca terutama membaca cerita tapi tidak ingin dipusingkan dengan bawaan buku-buku yang berat. Maka, bisa mengandalkan Wattpad. Melalui Wattpad pengguna bisa membaca apa saja sesuai genre yang disukai, baik itu fan-fiction, teen-fiction, romance, action dan genre-genre lainnya, tanpa harus di pusingkan dengan bawaan buku - buku yang berat. Cukup dengan membuka alamat websitenya atau membuka aplikasi Wattpad dengan mudah dan bisa mengaksesnya kapanpun dan dimanapun.

Dan untuk yang hobi menulis, tapi tidak tahu harus menulis dimana. Pengguna bisa mencoba menulis di Wattpad. Wattpad bisa menjadi tempat untuk melatih kemampuan menulis. Melalui Wattpad juga bisa bertukar ide tentang sebuah tulisan ataupun tentang bacaan. Juga menambah pengetahuan tentang menulis dengan cara membaca cerita. Dan jika beruntung dan mempunyai viewer yang banyak di Wattpad serta banyak yang menyukai tulisan-tulisan pengguna di situs ini, hingga ada yang ingin tulisan-tulisan tersebut dibukukan, dengan kata lain pengguna bisa mendapatkan penghasilan dari buku yang dicetak untuk dijual. Bahkan cerita tersebut juga bisa sampai difilmkan.

Sudah banyak cerita Wattpad yang dilirik penerbit dan dijadikan buku. Salah satu cerita Wattpad yang sudah di bukukan dan menjadi Novel Best Seller karena cerita ini sudah dibaca oleh lebih dari 20 juta pengguna yaitu "Dear Nathan" karya Erisca Febriani. dan bahkan dari Novel Best Seller ada rumah produksi yang meminta Dear Nathan untuk diangkat menjadi sebuah film. Film yang tayang pada tahun 2017 ini sukses meraup 700.165 ribu penonton.

Seperti yang dijelaskan sebelumnya bahwa kebanyakan orang yang menggunakan media sosial adalah para remaja. Anak remaja yang menggunakan media 
sosial sebagai tempat untuk menyalurkan kreatifitas, salah satunya kreatifitas menulis. Dalam membangkitkan kreatifitas remaja, salah satu hal yang dibutuhkan adalah motivasi. Purwanto (2007) menyatakan tujuan dari motivasi adalah untuk menggerakkan atau menggugah seseoarang agar timbul keinginan dan kemauannya untuk melakukan sesuatu sehingga dapat memperoleh hasil atau mencapai tujuan tertentu. Sardiman (2014) menyatakan bahwa motivasi serangkaian usaha untuk menyediakan kondisi-kondisi tertentu, sehingga seseorang mau dan ingin melakukan sesuatu, dan bila ia tidak suka, maka akan berusaha untuk meniadakan atau mengelakkan perasaan tidak suka itu. Jadi motivasi itu dapat dirangsang oleh faktor dari luar tetapi motivasi itu adalah tumbuh di dalam diri seseorang.

\section{Metode Penelitian}

Metode penelitian yang peneliti gunakan adalah melalui metode deskriptif kualitatitf. Deskriptif kualitatif adalah sebagai prosedur penelitian yang menghasilkan data deskriptif berupa kata-kata tertulis atau lisan dari orang-orang dan perilaku yang dapat diamati (Moleong, 2007).

\section{Hasil Penelitian dan Pembahasan}

Dari hasil penelitian yang telah di lakukan ternyata Wattpad ini memiliki kelebihan, terutama dalam membangkitkan minat membaca melalui media online di kalangan siswa khususnya dilokasi penelitian yakni di SMA Muhammadiyah 01 Medan. Siswa mengaku sangat menyukai cerita-cerita atau novel online yang di publish di aplikasi Wattpad berbasis Android. Mereka memilih android karena dianggap lebih praktis dan mudah dibawa kemana pun, daripada harus membawa laptop / PC yang berbasis internet.

Para narasumber selain menggunakan wattpad juga akrab dengan aplikasi-aplikasi pada media sosial lainnya seperti, Bbm, Line, WhatsApp, Instagram, dan Facebook. Mereka mengaku sering mengakses aplikasi-aplikasi tersebut untuk mencari informasi terkini atau hanya untuk sekedar memberi kabar pada keluarga, saudara maupun sahabat. 
Narasumber menyatakan

bahwa mereka menikmati ceritacerita atau novel yang dipublish di Wattpad, bahkan diantara mereka ada yang menyatakan merasa menyatu saat membaca cerita-cerita / novel yang dipublish di Wattpad. Mereka mengaku saat membaca sebuah cerita / novel yang di publish di Wattpad ini merasa bahwa, mereka merupakan pemeran dari cerita tersebut, bahkan terbawa suasana pada saat membaca cerita tersebut. Berbagai ekspresi mereka tunjukkan, ada yang tertawa saat membaca cerita yang lucu, ada yang menangis saat membaca cerita yang menyentuh hati, sampai ada yang kesal atau marah saat membaca alur cerita yang tidak seusai dengan apa yang ada dibenak masing-masing pembaca.

Mereka menganggap ceritacerita / novel yang di publish di Wattpad lebih efektif dari pada membaca sebuah novel bebentuk fisik (buku). Mereka mengaku, dengan menggunakan aplikasi Wattpad lebih mudah dan praktis, cukup menggunakan internet saat mencari berbagai cerita yang di inginkan, setelah cerita di masukan ke Library pada akun Wattpad mereka sudah bisa membaca seluruh isi cerita tersebut walaupun sedang offline. Karena, jika membeli novel buat kalangan remaja adalah suatu hal yang relatif sulit untuk dibeli.

Salah seorang narasumber menyatakan , Wattpad adalah sarana untuk menuangkan imajinasi dalam bentuk tulisan. Karena dengan aplikasi Wattpad ini, pengguna bisa membaca cerita-cerita / novel secara gratis dan bisa menuangkan imajinasi saat membaca cerita. Cerita yang ditulisnya merupakan cerita bergenre "Teen Fiction" yang berjudul "The Stupid Girl” yang mengisahkan tentang seorang cewek yang bodoh dalam hal pelajaran, kemudian bertemu dengan seorang cowok yang sangat pintar namun memiliki sifat sombong dan selalu merendahkan si cewek.

Berdasarkan temuan yang didapatkan, para pengguna Wattpad menjadikan internet dan aplikasi Wattpad sebagai sarana untuk menyampaikan pesan mereka. Pesanpesan tersebut adalah berupa ceritacerita yang mereka tulis atau baca, kemudian disebarkan untuk menarik atensi pengguna Wattpad, yang mana 
aplikasi ini sendiri diperuntukkan bagi masyarakat dunia maya yang hobi dalam membaca maupun menulis.

Dengan adanya salah satu faktor pendukung yang mendasari terjadinya komunikasi antara pengguna yang satu dengan yang lainnya seperti berada di tempat dalam bidang yang sama. Dalam hal ini, ketertarikan pengguna dengan dunia membaca dan menulis membuat para pengguna Wattpad lebih mudah untuk menjalin hubungan satu sama lain. Konvergensi juga membuat suatu hubungan yang lebih personal, dimana tidak hanya membaca atau pun menulis cerita, para pengguna juga dapat berkomunikasi satu sama lain dalam aplikasi Wattpad ini melalui komentar yang pembaca cantumkan dalam sebuah cerita yang di publish oleh penulis.

Dunia tulisan dan bacaan tentu dunia yang luas, aplikasi Wattpad menggolongkan cerita sesuai dengan genre tertentu, agar para pembaca lebih mudah dalam mencari suatu cerita yang di sukai. Begitu pula dengan para penulis yang menulis tulisan mereka, dan menggolongkannya dalam genre tertentu pula. Dengan adanya pengalaman dan dasar pegetahuan menjadi salah satu faktor untuk menarik minat pengguna lain yang memiliki pengalaman dan dasar pengetahuan yang sama menjadi sasaran tersampaikannya pesanpesan dibalik cerita-cerita yang konsumsi.

\section{Penutup}

Pada umumnya siswa SMA Muhammadiyah 01 Medan yang menjadi objek penelitian ini memiliki motivasi dan keinginan untuk menulis di aplikasi Wattpad. Walaupun sebagian dari mereka belum berani melakukan hal itu dengan alasan kurang percaya diri. Ada salah satu siswa yang telah aktif menjadi pembaca bahkan penulis di aplikasi Wattpad ini yang menghasilkan beberapa part (bagian) cerita, bahkan tulisan itu sudah dibaca ribuan kali dan mendapat ratusan dukungan suara (komentar) dari pengguna lain. 


\section{Daftar Pustaka}

Alwi Shahab. 2000. Internet Bagi Profesi Kedokteran. Jakarta: EGC.

Bungin, Burhan. 2013. Sosiologi Komunikasi. Jakarta: Kencana.

Kaplan, A.M. \& Muchael Haenlein (2010), Users of the world, unite! The challenges and opportunities of social media. Bussines Horizons, 53 (1): 59 68.

Moleong, Lexy J. 2007. Metodologi Penelitian Kualitatif (Edisi Revisi). Bandung:Remaja Rosdakarya.

Nasrullah, Rulli. 2015. Media Sosial. Bandung: PT Remaja Rosdakarya.

Purwanto, Ngalim M. 2007. Psikologi Pendidikan. Bandung: Remaja Rosdakarya

Sardiman, A.M. 2014. Interaksi dan Motivasi Belajar Mengajar. Jakarta: Rajawali Pers. 